\title{
Effect of First Aid Management of Dental Avulsion Posters on Primary School Teachers' Knowledge
}

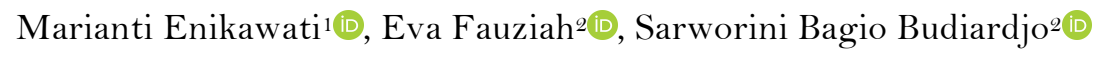

${ }^{1}$ Pediatric Dentistry Residency Program, Faculty of Dentistry, Universitas Indonesia, Jakarta, Indonesia.

${ }^{2}$ Department of Pediatric Dentistry, Faculty of Dentistry, Universitas Indonesia, Jakarta, Indonesia.

Author to whom correspondence should be addressed: Eva Fauziah, Department of Pediatric Dentistry, Faculty of Dentistry, Universitas Indonesia, Jl. Salemba Raya No.4, Jakarta Pusat, Jakarta 10430, Indonesia. Phone: +628129440574. E-mail: eva.fauziah@ui.ac.id.

Academic Editor: Alessandro Leite Cavalcanti

Received: 29 March 2020 / Review: 27 April 2020 / Accepted: 22 June 2020

How to cite this article: Enikawati M, Fauziah E, Budiardjo SB. Effect of first aid management of dental avulsion posters
on primary school teachers' knowledge. Pesqui Bras Odontopediatria Clín Integr. 2020; 20 :e0061.
https://doi.org/10.1590/pboci.2020.159

\begin{abstract}
Objective: To investigate the effect of deploying a "First Aid Management of Dental Avulsion" poster in a primary school setting to improve teachers' knowledge. Material and Methods: The present study was conducted at public primary schools in central Jakarta, with 54 teachers meeting the inclusion criteria. The questionnaire contained 13 questions, divided into two sections. The first section consisted of questions about sex, age, education, length of service, field of education, and whether the teacher had received first aid management education before. The second section consisted of 7 questions about the teacher's knowledge regarding dental avulsion and its management. Baseline knowledge was defined by using a questionnaire and then teachers were shown the educational poster covering the first aid management of dental avulsion. Next, the teachers answered a post-education questionnaire, which included the same questions as the first questionnaire. A paired t-test or Wilcoxon's signed-rank test was used based on the distribution of data to determine the significance of the differences between before and after education. Results: The median score before reading the poster was 5 , while the median score after reading it was 10 . The difference was statistically significant. Conclusion: "First Aid Management of Dental Avulsion" poster could improve the knowledge of primary school teachers in Jakarta.
\end{abstract}

Keywords: Tooth Injuries; Tooth Avulsion; Poster; First Aid; School Teachers. 


\section{Introduction}

Around 5\% of trauma incidence is trauma in the oral region and often occurs in children and young adults [1-3]. According to existing research, around $25 \%$ of schoolchildren in the world have experienced dental trauma, although its prevalence varies among different countries [4-6]. Research from India states that the prevalence of dental trauma in children was $14.4 \%$, while other reports reveal rates of $33.8 \%$ in Jerusalem, Israel; $11.4 \%$ in Canada; and $66.6 \%$ in Chile [2].

In Indonesia, according to a study conducted in the Jakarta area in 2014, the prevalence rates of oral trauma among 8-12 year-olds were $17 \%$ in boys and $8 \%$ in girls [2,4,5,7-11]. Dental avulsion is the most severe type of oral trauma [9,12]. An avulsion is a complete displacement of the tooth from its socket in the alveolar bone [1,8]. More than 5 million teeth are avulsed each year in the United States, and the most frequent injuries occur at school $[5,13]$.

Research suggests that $64.5 \%$ of dental avulsion cases were not treated properly at the time of occurrence because the avulsed tooth was lost during the incident [8]. This can happen partly due to a lack of awareness and knowledge of the child and the people around them. Many studies have been conducted in various countries and support that schoolteachers' knowledge regarding first aid in dental avulsion is still low [3,9-11]. One study found that awareness of teachers was only $1 \%$ [14]. In Indonesia, to the best of our knowledge, there has been no research conducted on the knowledge of first aid management of dental avulsion among schoolteachers.

One of the most common treatments for avulsion is replantation [12]. However, the prognosis of replantation depends upon the first aid received during the event, so people in the environment around the affected children, such as teachers, must have a good knowledge regarding emergency management of dental trauma to increase the chances of success [3,11,14-17]. Therefore, these individuals need education to improve their knowledge. Educational posters are among the most common media types used for public education [18], accessible, clear, easy to distribute, and inexpensive [4,19]. Some studies have shown that the deployment of educational posters can significantly improve knowledge [4,5,18]. However, no study considered the effect of a poster on first aid management of dental avulsion education in Indonesia had been done before. On the other hand, the prevalence of dental trauma in Indonesia is quite high, 17\% in boys, and 8\% in girls [7]. Ensuring the education of teachers regarding this point is essential. The aim of this study was to investigate the effect of a "First Aid Management of Dental Avulsion” Poster on primary school teachers' knowledge.

\section{Material and Methods}

Ethical Approval

The present research project was approved by the Ethical Committee of the Faculty of Dentistry, University of Indonesia (no. 23/ethical approval/FKGUI/III/2019).

\section{Subjects}

The study subjects were primary schoolteachers of 13 public schools in central Jakarta with a minimum education of Diploma IV who had never before received any dental first aid management education before and agreed to participate in the study. The sampling technique used in this study was convenience sampling, and 54 teachers met the inclusion criteria for this study.

Questionnaire 
The questionnaire was written in Bahasa, Indonesia. Before conducting the present study, the researchers ensured the reliability of the questionnaire among 30 teachers who were not included in the final sample (Cronbach alpha $=0.80)$. A total of 13 questions, divided into two sections, were included. The first section consisted of questions about sex, age, education, length of service, field of education, and whether the teacher had received first aid management education before. The second section consisted of 7 questions about the teacher's knowledge regarding dental avulsion and its management. Incorrect answers were scored as zero points, while 2 points were awarded for correct answers. When there was more than 1 correct answer, zero points were awarded for incorrect answers, 1 point was awarded for 1 correct answer, and 2 points were awarded for more than 1 correct answer. Given there were 7 questions in this section about the teacher's knowledge, the total possible score was 14 points. A total of 2 questionnaires were delivered - before and after the education initiative, respectively - consisting of the same questions.

Poster

The poster size was A2, printed on 230-gr paper, and written in Bahasa Indonesia. It was designed based on the Dental Trauma Guidelines from the International Association for Dental Traumatology, which explained about dental avulsion and its first aid management [12]. The included picture was made by an animator.

\section{Education Method}

At the initial stage, the researcher provided information both verbally and written about the research. The teachers filled out informed consent forms stating their willingness to participate in the study. The teachers then filled out the questionnaire consisting of demographic data and questions about their first aid knowledge of dental avulsion. After they filled out this questionnaire, they read the "First Aid Management of Dental Avulsion" education poster without an oral explanation from the researcher. After reading the poster, the teachers completed the post-education questionnaire.

\section{Data Analysis}

All collected data were analyzed using the Statistical Package for the Social Sciences version 22 software program (IBM Corp., Armonk, NY, USA). A paired t-test or Wilcoxon's signed-rank test was used based on distribution of data to determine the significance of the differences between before and after education. The significance level was set at $5 \%$.

\section{Results}

A total of 54 teachers out of 58 teachers from 13 schools met the inclusion criteria and agreed to fill out the questionnaire. Table 1 presents the demographic data of the respondents. Most of the participants were female (74.1\%), with bachelor's degrees (77.8\%) and teach other subjects besides physical education (85.2\%). The number of respondents in each age group varied and did not differ much except in 30 years or less age group $(9.3 \%)$. The length of career varied, with most of the teachers having more than 10 years of teaching experience.

The scores for each question, along with the average score before and after education, are shown in Table 2 . 
Table 1. Demographic details.

\begin{tabular}{|c|c|c|}
\hline Variables & $\mathbf{N}$ & $\%$ \\
\hline \multicolumn{3}{|l|}{ Sex } \\
\hline Male & 14 & 25.9 \\
\hline Female & 40 & 74.1 \\
\hline \multicolumn{3}{|l|}{ Age Group } \\
\hline$\leq 30$ Years & 5 & 9.3 \\
\hline $31-40$ Years & 19 & 35.2 \\
\hline $41-50$ Years & 16 & 29.6 \\
\hline$>50$ Years & 14 & 25.9 \\
\hline \multicolumn{3}{|l|}{ Education Level } \\
\hline Diploma & 3 & 5.6 \\
\hline Bachelor & 42 & 77.8 \\
\hline Masters & 9 & 16.7 \\
\hline \multicolumn{3}{|l|}{ Length of Service } \\
\hline O-5 Years & 8 & 14.8 \\
\hline 6-10 Years & 8 & 14.8 \\
\hline 11-20 Years & 20 & 37.1 \\
\hline$>20$ Years & 18 & 33.3 \\
\hline \multicolumn{3}{|l|}{ Field of Education } \\
\hline Not a Physical Education Teacher & 46 & 85.2 \\
\hline Physical Education Teacher & 8 & 14.8 \\
\hline
\end{tabular}

Table 2. Comparison of individual knowledge scores before and after reading the poster.

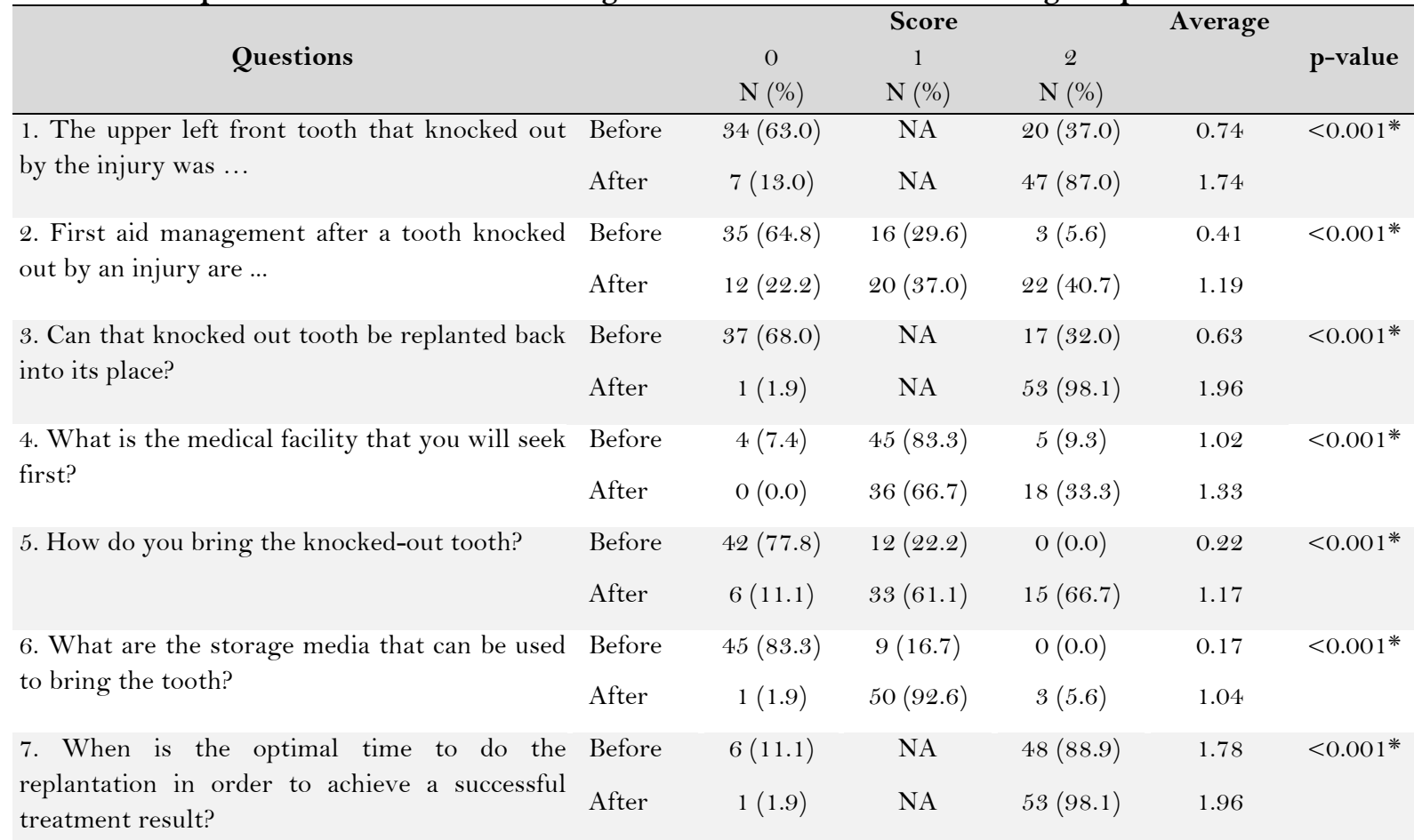

Wilcoxon test; *Statistically Significant; NA: Not Available; Questions 1, 3, and 7 have only 1 correct answer; Questions 2, 4, 5, and 6 had more than 1 correct answer.

In general, the median score before education was 5 points (range: 1-10 points). After education, the median score was 10 points (range: 4-14 points). Statistics showed a significant difference between before and after the poster deployment $(\mathrm{p}<0.001)$. 
Table 3. Comparison of total knowledge scores before and after reading the poster.

\begin{tabular}{cccc}
\hline Total Knowledge Score & N & Median (Minimum-Maximum) & p-value \\
\hline Before & 54 & $5(1-10)$ & $<0.001^{*}$ \\
After & 54 & $10(4-14)$ & \\
\hline *Wilcoxon test. & & &
\end{tabular}

\section{Discussion}

The median scores of baseline knowledge was 5 and after education was 10. As can be seen, the median score of baseline knowledge was poor but increased significantly after education. It can be concluded that the "First Aid Management of Dental Avulsion" poster can improve the knowledge of teachers who view it. There was an increase in the largest score and maximum score between before education and after education, in parallel with previous studies stating that educational poster use can significantly improve teacher knowledge [4,5,9].

There was also a statistically significant difference in each question, which means that the educational poster can deliver the presented information well and be an effective educational media option. The highest score increase was seen with question no. 3, "Can the knocked-out tooth be replanted back into its place?" This is in line with a study in India, which stated that only $22 \%$ of schoolteachers knew that an avulsed tooth could be replanted back into its socket [20]. This question is the most important of all the questions in the questionnaire because it illustrates that, through education using the educational poster, the teachers can come to know that avulsed teeth can be replanted back into their sockets.

Conversely, the lowest score of escalation was seen with question no. 7. As can be seen, $88.9 \%$ of subjects answered this question correctly before being educated, which means that many teachers already knew that the best time to conduct the replantation is immediately. A study in Brazil found that regarding the urgency of finding a professional to treat an avulsed permanent tooth, $88.5 \%$ of teachers answered immediately. This shows that they are not totally ignorant regarding the management of dental injuries like avulsion injury $[20,21]$. On the other hand, a study in Iran reported that only $38.5 \%$ of teachers answered immediately. It is mentioned that this might have happened because they were more concerned with stopping the bleeding [22].

For question number 1, before education, $63 \%$ did not know the fractured tooth was a permanent tooth in the example 9-year-old student. This condition may lead to improper management of avulsed teeth and reduce the prognosis. Our data are consistent with the study carried out in Iran that stated that $61 \%$ of respondents did not know that the tooth displayed was a permanent tooth [22]. This may be caused by a lack of education from the government regarding dental and oral health. Apparently, after education, $87 \%$ answered correctly, showing that education was effective.

From the first questionnaire, we know that there are many teachers who did not know how to collect the knocked out tooth and don't know the storage media that can be used to contain the tooth. As mentioned in other studies, the level of teachers' knowledge about the first aid of dental avulsion is still very low [9,11,20,2 1,23]. Most teachers suggested alcohol and disinfectant, which can compromise tissue repair and create a poor prognosis of the replantation. This is similar to in some other studies revealing that many teachers have poor knowledge about optimal storage media to contain the avulsed tooth while awaiting replantation $[14,22,24]$. This can occur due to a lack of education among primary schoolteachers regarding the first aid management of dental trauma.

Further, many people are not familiar with storage media such as HBSS and saline. HBBS is also not generally available in Indonesia [25]. After education through poster viewing, there was a significant decrease 
in incorrect answers from $83.3 \%$ to $1.9 \%$, indicating that the education was successful. A previous research also observed a significant increase in the correct answer rate regarding storage media that can be used to carry avulsed teeth from $3 \%$ to $94 \%$. The results of this study are in agreement with previous report [24]. This might have occurred because of the similarity of the methods used. In addition, some studies stated that primary schoolteachers abroad also do not receive adequate education about the first aid management of dental avulsion.

This study was a preliminary study and the topic has not been explored before in Indonesia. The limitations of this study are the limited number of samples and the small area of coverage; therefore, additional research with a wider coverage area and a greater number of samples is needed. However, despite the limitations, our data emphasize a need for further dental health education and teachers' training regarding managing dental trauma. Considering the incidence of trauma at home is also quite high, other research on the home environment also is warranted. Follow-up is also needed to find out whether the information obtained is remembered or not and for how long. From this study, we can conclude that educational posters are effective educational media to improve knowledge. This is similar to previous studies stating that educational posters can be effective media in dental trauma education [26].

\section{Conclusion}

There was a statistically significant difference in primary school teachers' knowledge regarding the first aid management of dental avulsion between before and after viewing an educational poster. In other words, the "First Aid Management of Dental Avulsion" poster effectively improved the primary schoolteacher's knowledge.

\section{Authors' Contributions}

\begin{tabular}{|c|c|c|}
\hline ME & (iD) $0000-0002-5844-2085$ & Investigation, Formal Analysis and Writing - Original Draft Preparation. \\
\hline $\mathrm{EF}$ & (iD) $0000-0002-8785-5874$ & Conceptualization, Methodology and Writing - Review and Editing. \\
\hline SBB & (iD) $0000-0002-2506-6191$ & Writing - Review and Editing. \\
\hline
\end{tabular}

\section{Financial Support}

HIBAH PITTA (Grant No. NKB-0566/UN2.R3.1/HKP 05.00/2019), University of Indonesia.

\section{Conflict of Interest}

The authors declare no conflicts of interest.

\section{Acknowledgments}

The researcher would like to thank all of the principals who were willing to take part in this research.

\section{References}

[1] Andreasen JO, Andreasen FM, Andersson L. Textbook and Color Atlas of Traumatic Injuries to the Teeth. Hoboken: Wiley; 2013.

[2] Zaleckiene V, Peciuliene V, Brukiene V, Drukteinis S. Traumatic dental injuries: etiology, prevalence and possible outcomes. Stomatologija 2014; 16(1):7-14.

[3] Al Sari S, Kowash M, Hussein I, Al-Halabi M. An educational initiative for Dubai school nurses and physical education teachers on the management of traumatic dental injuries. J Sch Nurs 2019; 35(5):359-66. https://doi.org/10.1177/1059840518780306 
[4] Young C, Wong KY, Cheung LK. Effectiveness of educational poster on knowledge of emergency management of dental trauma - part 2: cluster randomised controlled trial for secondary school students. PLoS One 2014; 9(8):e101972. https://doi.org/10.1371/journal.pone.0101972

[5] Ghadimi S, Seraj B, Keshavarz H, Shamshiri AR, Abiri R. The effect of using an educational poster on elementary school health teachers' knowledge of emergency management of traumatic dental injuries. J Dent 2014; 11(6):620-8.

[6] Diangelis AJ, Andreasen JO, Ebeleseder KA, Kenny DJ, Trope M, Sigurdsson A, et al. Guidelines for the management of traumatic dental injuries: 1. Fractures and luxations of permanent teeth. Pediatr Dent 2017; 39(6):401-1 1. https://doi.org/10.1111/j.1600-9657.2011.01103.x

[7] Ikaputri A, Sutadi H, Fauziah E. Distribution frequency of traumatic permanent anterior teeth on children aged 812 years study in State Elementary School District of Joharbaru Central Jakarta. Fakultas Kedokteran Gigi Universitas: University of Indonesia; 2014.

[8] Karayilmaz H, Kirzioglu Z, Gungor OE. Aetiology, treatment patterns and long-term outcomes of tooth avulsion in children and adolescents. Pak J Med Sci 2013; 29(2):464-8. https://doi.org/10.12669/pjms.292.3283

[9] Al-Asfour A, Andersson L, Al-Jame Q. School teachers' knowledge of tooth avulsion and dental first aid before and after receiving information about avulsed teeth and replantation. Dent Traumatol 2008; 24(1):43-9. https://doi.org/10.1111/j.1600-9657.2006.00476.x

[10] Young C, Wong KY, Cheung LK. Emergency management of dental trauma: knowledge of Hong Kong primary and secondary school teachers. Hong Kong Med J 2012; 18(5):362-70.

[11] Fux-Noy A, Sarnat H, Amir E. Knowledge of elementary school teachers in Tel-Aviv, Israel, regarding emergency care of dental injuries. Dent Traumatol 2011;27(4):252-6. https://doi.org/10.1111/j.1600-9657.2010.00970.x

[12] Andersson L, Andreasen JO, Day P, Heithersay G, Trope M, Diangelis AJ, et al. International association of dental traumatology guidelines for the management of traumatic dental injuries: 2. Avulsion of permanent teeth. Dent Traumatol 2012; 28(2):88-96. https://doi.org/10.1111/j.1600-9657.2012.01125.x

[13] Young EJ, Macias CR, Stephens L. Common dental injury management in athletes. Sports Health 2015; 7(3):250-5. https://doi.org/10.1177/1941738113486077

[14] Attarzadeh H, Kebriaei F, Sadri L, Foroughi E, Taghian M. Knowledge and attitudes of elementary schoolteachers on dental trauma and its management in Yazd, Iran. J Dent 2017; 18(3):212-8.

[15] Kirby J, Rogers H, Agel M, Gilchrist F. Immediate management of avulsion injuries in children. Dent Update 2017; 44(8):713-23. https://doi.org/10.12968/denu.2017.44.8.713

[16] Prasanna S, Giriraju A, Narayan NL. Knowledge and attitude of primary school teachers toward tooth avulsion and dental first aid in Davangere City: A cross-sectional survey. Int J Clin Pediatr Dent 2011; 4(3):203-6. https://doi.org/10.5005/jp-journals-10005-1110

[17] Ersin N, Ertugrul F, Oncag O, Menderes M, Uzel I. Evaluation of high risk university students' knowledge about dental trauma and emergency procedures. J Int Dent Med Res 2013; 6(3):100-4.

[18] Lieger O, Graf C, El-Maaytah M, Von Arx T. Impact of educational posters on the lay knowledge of school teachers regarding emergency management of dental injuries. Dent Traumatol 2009; 25(4):406-12. https://doi.org/10.1111/j.1600-9657.2009.00798.x

[19] Djemal S, Singh P. Smartphones and dental trauma: The current availability of apps for managing traumatic dental injuries. Dent Traumatol 2015; 32(1):52-7. https://doi.org/10.1111/edt.12217

[20] Mohandas U, Chandan GD. Knowledge, attitude and practice in emergency management of dental injury among physical education teachers: a survey in Bangalore urban schools. J Indian Soc Pedod Prev Dent 2009; 27(4):242-8. https://doi.org/10.4103/0970-4388.57660

[21] Ludgero AL, Santos TS, Fernandes AV, Melo DG, Peixoto AC, Araujo FAC, et al. Knowledge regarding emergency management of avulsed teeth among elementary school teachers in Jaboatao dos Guararapes, Pernambuco, Brazil. Indian J Dent Res 2012; 23(5):585-90. https://doi.org/10.4103/0970-9290.107331

[22] Raoof M, Zaherara F, Shokouhinejad N, Mohammadalizadeh S. Elementary school staff knowledge and attitude with regard to first-aid management of dental trauma in Iran: a basic premise for developing future intervention. Dent Traumatol 2012; 28(6):441-7. https://doi.org/10.1111/j.1600-9657.2011.01085.x

[23] Bayrak S, Tunc ES, Sari E. Evaluation of elementary school teachers' knowledge and attitudes about immediate emergency management of traumatic dental injuries. Oral Health Prev Dent 2012; 10(3):253-8.

[24] Niviethitha S, Bhawarlal C, Ramkumar H, Dhakshanamoorthy S, Shanmugam H. Effectiveness of an áudio-visual aid on the knowledge of school teachers regarding emergency management of dental injuries. Dent Traumatol 2018; 34:290-6. https://doi.org/10.1111/edt.12405

[25] Arrizza AM, Ramadhan AF. Coconut water (Cocos nucifera) as storage media for the avulsed tooth. J Dent Indon 2010; 17(3):74-9. https://doi.org/10.14693/jdi.v17i3.39

[26] McIntyre JD, Lee JY, Trope M, Vann Jr WF. Elementary school staff knowledge about dental injuries. Dent Traumatol 2008; 24(3):289-98. https://doi.org/10.1111/j.1600-9657.2007.00542.x 